\title{
Clinical presentation and outcome of epidemic Kaposi sarcoma in Ugandan children
}

Soren Gantt ${ }^{1,2^{*}}$, Abel Kakuru ${ }^{3,4}$, Anna Wald ${ }^{2}$, Victoria Walusansa ${ }^{3,4}$, Lawrence Corey ${ }^{2,5}$, Corey Casper ${ }^{2,5}$, Jackson Orem ${ }^{3,4}$

From $12^{\text {th }}$ International Conference on Malignancies in AIDS and Other Acquired Immunodeficiencies (ICMAOI)

Bethesda, MD, USA. 26-27 April, 2010

\section{Background}

Kaposi sarcoma (KS) is one of the most common pediatric cancers in sub-Saharan Africa. Few data are available about the clinical presentation or response to treatment of children with epidemic (HIV-associated) KS.

\section{Methods}

Medical records of all children with KS and HIV infection referred to the Uganda Cancer Institute from October 2004 to June 2007 were reviewed. Charts were abstracted for age, sex, location of KS lesions, biopsy results, CD4 T-cell counts, and KS treatment and outcome. (Table 1)

Those children with lymphadenopathic KS were younger (mean difference 3.7 years; $\mathrm{p}=0.01$ ), and had higher CD4 T-cell counts (mean difference 242 cells/ $\mu \mathrm{L}$; $\mathrm{p}=0.03)$ than those without lymph node involvement.
CD4 T-cell count was not associated with KS presentations other than lymph node involvement (Figure 1).

Twenty children $(62.5 \%)$ of the 32 patients with outcome data available had a complete resolution of KS. Eleven patients had a partial response, and only one patient had a documented lack of response. No association was apparent between outcome and age, sex, or type of KS presentation. Thirty (93.8\%) of the 32 patients with outcome data available received cancer chemotherapy (10 with vincristine, 20 with vincristine plus bleomycin). No difference was observed in outcome with respect to whether cancer chemotherapy was used, or whether one or two drugs were given. Of those patients with a known outcome, a higher proportion had a complete resolution of KS among those who received any antiretroviral therapy (ART) regimen compared to those who did not receive ART ( 19 of 26 vs. 1 of $6 ; \mathrm{P}=0.02$ ).

Table 1

\begin{tabular}{|c|c|c|c|}
\hline & Total & Males & Females \\
\hline KS cases, n (percent) & $73(100 \%)$ & $37(50.7 \%)$ & $36(49.3 \%)$ \\
\hline Age in years, median (range), $\mathrm{n}=56$ & $10.1(2-18)$ & $9.3(2-16)$ & $11.0(2-18)$ \\
\hline CD4 T-cells/uL, median (IQR) n=36 & $210(21-482)$ & $165(16-538)$ & $263(26-464)$ \\
\hline \multicolumn{4}{|l|}{ Location of lesions $n=42^{*}$} \\
\hline Skin involvement & $20(47.6 \%)$ & $10(45.5 \%)$ & $10(50.0 \%)$ \\
\hline Oral cavity involvement & $9(21.4 \%)$ & $4(20.0 \%)$ & $5(22.7 \%)$ \\
\hline Viscera involvement & $5(11.9 \%)$ & $3(15.0 \%)$ & $2(9.1 \%)$ \\
\hline Lymph node involvement & $25(59.5 \%)$ & $11(55.0 \%)$ & $14(58.3 \%)$ \\
\hline
\end{tabular}

"Categories of lesion location not mutually exclusive.

\footnotetext{
*Correspondence: sgantt@uw.edu

'Seattle Children's Hospital, Seattle, WA, USA

Full list of author information is available at the end of the article
} 


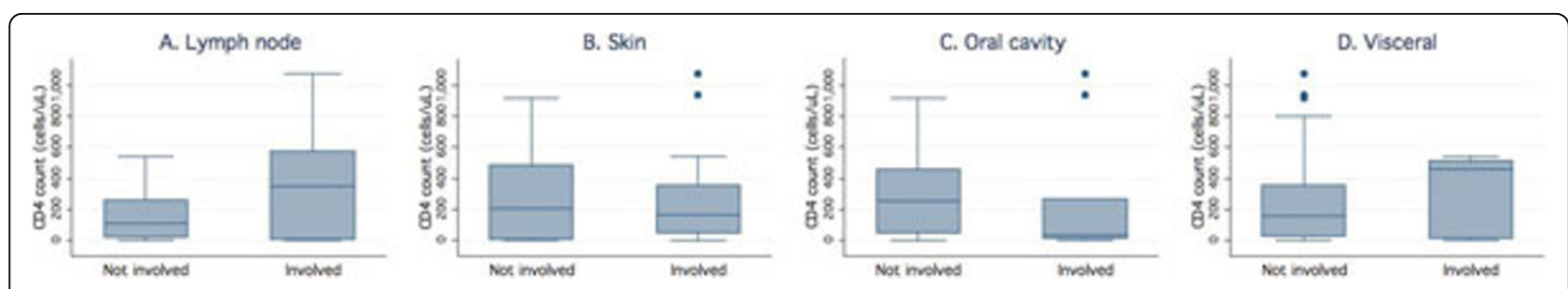

Figure 1 CD4 T-cell count quartiles (boxes and whiskers) and outliers (dots) for those patients with and without KS involvement of the lymph nodes (A), skin (B), oral cavity (C), and viscera (D).

\section{Conclusions}

Compared to skin involvement, lymph node involvement of epidemic KS occurs at younger ages and at higher CD4 levels. This presentation may reflect recent infection with human herpesvirus 8 followed by a rapid progression to malignancy. Favorable response to treatment was observed in some cases, but the observed response rate was almost certainly biased by the large number of children lost to followup, among whom we expect disproportionately poor outcomes. Prospective studies are needed to determine optimal management.

\section{Acknowledgements}

This article has been published as part of Infectious Agents and Cancer Volume 5 Supplement 1, 2010: Proceedings of the $12^{\text {th }}$ International Conference on Malignancies in AIDS and Other Acquired

Immunodeficiencies (ICMAOI). The full contents of the supplement are available online at http://www.biomedcentral.com/1750-9378/5? issue=S1.

\section{Author details}

'Seattle Children's Hospital, Seattle, WA, USA. 'University of Washington, Seattle, WA, USA. ${ }^{3}$ Uganda Cancer Institute, Kampala, Uganda. ${ }^{4}$ Makerere University College of Health Sciences, Kampala, Uganda. ${ }^{5}$ Fred Hutchinson Cancer Research Center, Seattle, WA, USA.

Published: 11 October 2010

doi:10.1186/1750-9378-5-S1-A12

Cite this article as: Gantt et al: Clinical presentation and outcome of epidemic Kaposi sarcoma in Ugandan children. Infectious Agents and Cancer 2010 5(Suppl 1):A12.

Submit your next manuscript to BioMed Central and take full advantage of:

- Convenient online submission

- Thorough peer review

- No space constraints or color figure charges

- Immediate publication on acceptance

- Inclusion in PubMed, CAS, Scopus and Google Scholar

- Research which is freely available for redistribution

Submit your manuscript at www.biomedcentral.com/submit 